\title{
Restriction Fragment Length Polymorphism
}

National Cancer Institute

\section{Source}

National Cancer Institute. Restriction Fragment Length Polymorphism. NCI Thesaurus.

Code C17093.

Variation occurring within a species in the leng th of DNA fragments generated by a specific endonuclease. Such variations are generated by mutations that create or abolish recognition sites for these enzymes. 